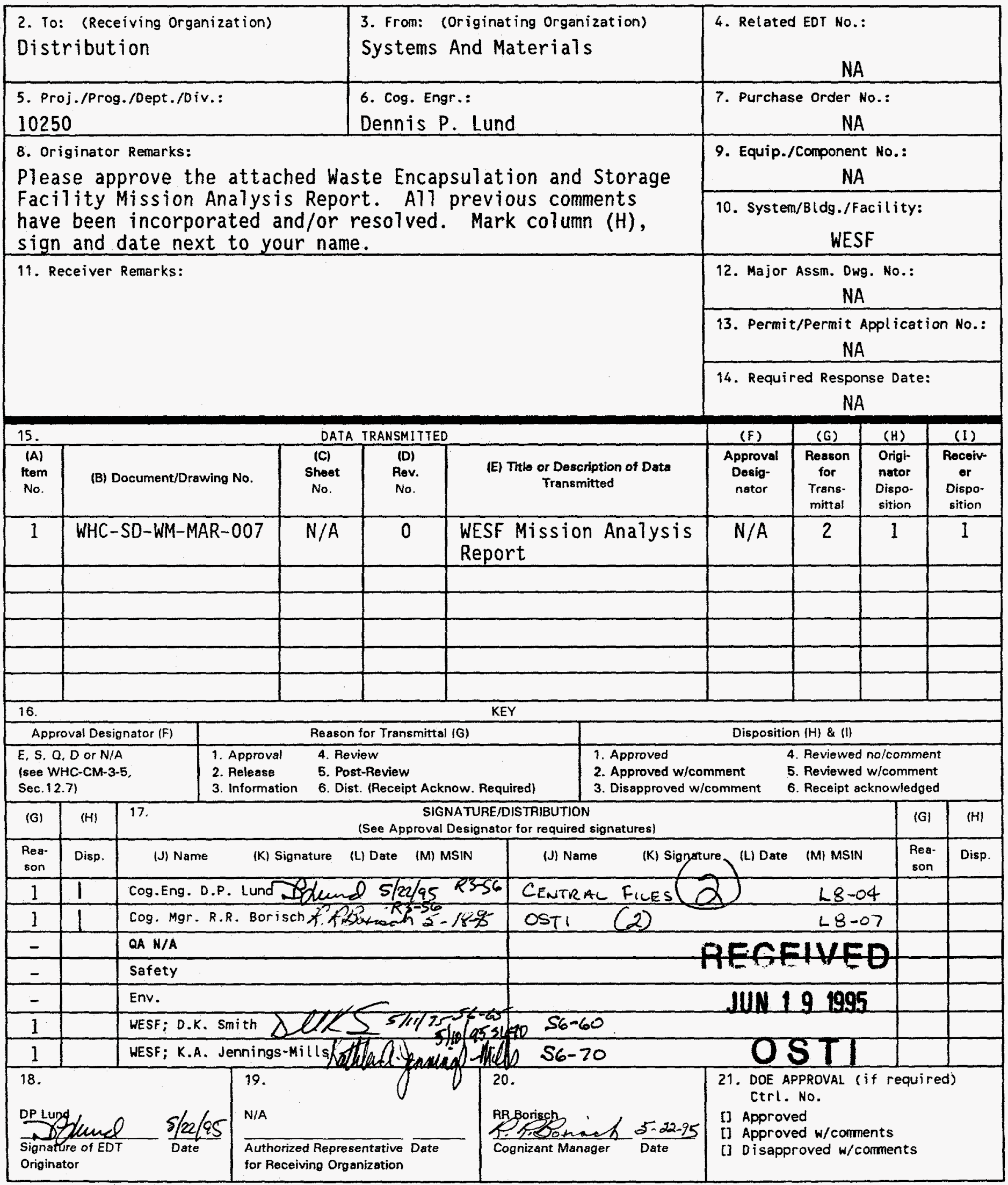




\section{DISCLAIMER}

Portions of this document may be illegible in electronic image products. Images are produced from the best available original document. 


\section{RELEASE AUTHORIZATION}

Document Number: WHC-SD-WM-MAR-007, Rev. 0

Document Title: WASTE ENCAPSULATION AND STORAGE FACILITY

MISSION ANALYSIS REPORT

Release Date: $\quad 5 / 24 / 95$

This document was reviewed following the procedures described in WHC-CM-3-4 and is:

\section{APPROVED FOR PUBLIC RELEASE}

WHC Information Release Administration Specialist:

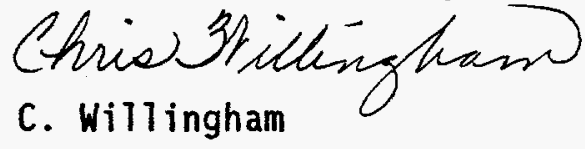

TRADEMARK DISCLAIMER. Reference herein to any specific commercial product, process, or service by trade name, trademark, manufacturer, or otherwise, does not necessarily constitute or imply its endorsement, recomendation, or favoring by the United states Government or any agency thereof or its contractors or subcontractors.

This report has been reproduced from the best available copy. Available in paper copy and microfiche. Printed in the United states of America. Available to the U.s. Department of Energy and its contractors from:

U.S. Depertment of Energy

office of Scientific and Technical Information (OSTI)

P.0. Box 62

Dak Ridge, TN 37831

Telephone: (615) 576-8401

Available to the public from:

U.S. Depertment of Commerce

National Technical Information Service (NTIS)

5285 Port Royal Road

Springfield, VA 22161

Telephone: (703) 487-4650 


\section{SUPPORTING DOCUMENT}

1. Total Pages 23

\begin{tabular}{|l|l|c|}
\hline $\begin{array}{l}\text { 2. Title } \\
\text { Waste Encapsulation and Storage Facility Mission } \\
\text { Analysis Report }\end{array}$ & $\begin{array}{l}\text { 3. Number } \\
\text { WHC-SD-WM-MAR-007 }\end{array}$ & $\begin{array}{c}\text { 4. Rev No. } \\
0\end{array}$ \\
\hline $\begin{array}{l}\text { 5. Key words } \\
\text { WESF Mission, Mission Analysis Report, WESF MAR }\end{array}$ & $\begin{array}{l}\text { 6. Authar } \\
\text { Name: DP Lund }\end{array}$ \\
\hline $\begin{array}{l}\text { signatore } \\
\text { Organization/Charge Codel0250/K123C }\end{array}$ \\
\hline
\end{tabular}

7. Abstract

\section{DISCLAIMER}

This report was prepared as an account of work sponsored by an agency of the United States Government. Neither the United States Government nor any agency thereof, nor any of their employees, makes any warranty, express or implied, or assumes any legal liability or responsibility for the accuracy, completeness, or usefulness of any information, apparatus, product, or process disclosed, or represents that its use would not infringe privately owned rights. Reference herein to any specific commercial product, process, or service by trade name, trademark, manufacturer, or otherwise does not necessarily constitute or imply its endorsement, recommendation, or favoring by the United States Government or any agency thereof. The views and opinions of authors expressed herein do not necessarily state or reflect those of the United States Government or any agency thereof.
8. RELEASE STAMP

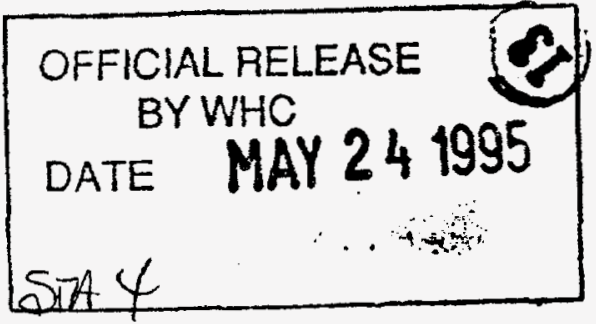




\title{
WASTE ENCAPSULATION AND STORAGE FACILITY MISSION ANALYSIS REPORT
}

\author{
April 1995
}

\author{
Prepared for: \\ WESTINGHOUSE HANFORD COMPANY \\ P. 0. Box 1970 \\ Richland, Washington 99352
}

Prepared by:

WESF Working Group 
TABLE OF CONTENTS

TABLE OF CONTENTS

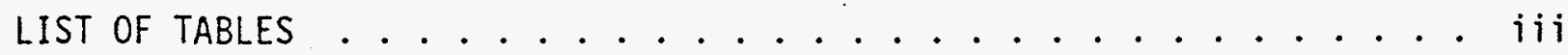

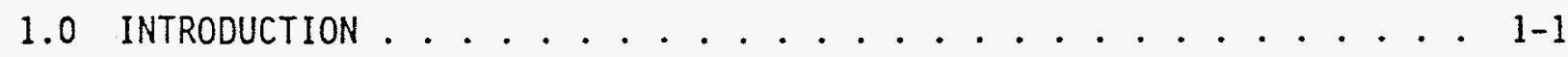

1.1 PURPOSE ........................... 1

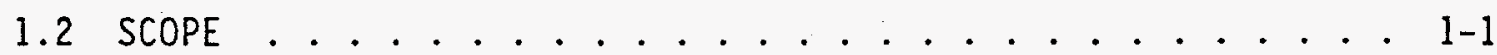

1.3 BACKGROUND .......................... $1-2$

1.4 PROBLEM STATEMENT . . . . . . . . . . . . . 1 . .

2.0 MISSION ANALYSIS . . . . . . . . . . . . . . . 2-1

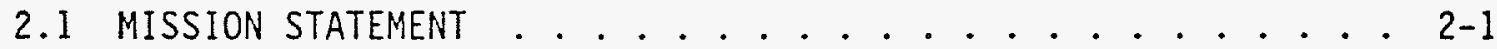

2.2 INITIAL CONDITIONS ..................... 2-1

2.3 FINAL CONDITIONS ..................... 2-1

2.4 MISSION BOUNDARIES AND EXTERNAL INTERFACES ....... 2-5

2.4.1 Mission Boundaries............ 2-5

2.4.2 External Interfaces ............ 2-5

2.5 MISSION RESOURCES ............... . . . . 2-7

2.6 MEASURES OF EFFECTIVENESS AND MEASURES OF SUCCESS . . . . 2-7

2.7 MEASURES OF MISSION RISK . . . . . . . . . . . . 2-9

2.8 MISSION FEASIBILITY . . . . . . . . . . . . 2-10

2.9 ISSUES . . . . . . . . . . . . . . . . 2-10

2.9.1 Key Decisions and Need Dates ......... . 2-10

2.9.2 Unvalidated Requirements and Assumptions ...... . 2-13

2.9 .3 Open Issues ............... 2- . . . . . . .

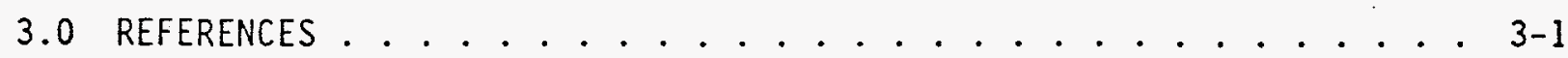

4.0 GLOSSARY ........................... . . . . . 


\section{LIST OF TABLES}

Table 1. WESF Initial Conditions. ............. 2-3

Table 2. WESF final Conditions. ............. 2- . . .

Table 3. WESF Structures ................ 2- . 2-6

Table 4. WESF Measures of Effectiveness .......... 2-8 


\subsection{INTRODUCTION}

\subsection{PURPOSE}

This report defines the mission for the Waste Encapsulation and Storage Facility (WESF). It contains summary information regarding the mission analysis which was performed by holding workshops attended by relevant persons involved in the WESF operations. The mission analysis defines the mission for the WESF system within the Hanford Sitewide context. It also defines the environment which effects the execution of the WESF mission. The WESF mission analysis process is consistent with the Hanford Site Systems Engineering Management PIan (HS-SEMP) and with the initial process steps of the integrated engineering model presented in the Hanford Site Systems Engineering Manual (HS-SEM).

\subsection{SCOPE}

The scope of the WESF mission is to provide storage of Cesium (CS) and Strontium (Sr) capsules, previously produced at WESF, until every capsule has been removed from the facility either to another storage location, for disposal or for beneficial use by public or private enterprises. Since the disposition of the capsules has not yet been determined, they may be stored at WESF for many years even decades. The current condition of the WESF facility must be upgraded and maintained to provide for storage which is safe, cost effective, and fully compliant with DOE direction as well as federal, state, and local laws and regulations. The Cs capsules produced at WESF were originally released to private enterprises for uses such as the sterilization of medical equipment; but because of the leakage of one capsule, all are being returned. The systems, subsystems, and equipment not required for the storage mission will be available for use by other projects or private enterprises. Several projects have expressed interest in using the facility for activities such as conducting pilot plant and treatment studies. Currently, hot cells $B$, $C, D \& E$ are inactive. The WESF mission does not include the following activities: deactivating the facility for decontamination and decommissioning (D\&D) once all CS and $S r$ have been removed, redesigning or repairing of capsules, or processing of leaking capsules. 


\section{WHC-SD-WM-MAR-007 Revision 0}

\subsection{BACKGROUND}

The Waste Encapsulation and Storage Facility (WESF) is located in the 200-E area at the U.S. Department of Energy's (DOE) Hanford Site and is physically attached to the west side of B Plant. WESF was constructed between 1970 and 1974 to support a primary waste management goal of removing and isolating high level radioactive waste produced by reprocessing nuclear fuel. An intermediate goal included the removal of the long-lived radionuclides, $137 \mathrm{CS}$ and $90 \mathrm{~S} r$, from the liquid radioactive wastes. These activities occurred in B Plant from 1968 through 1985. WESF received the concentrated $\mathrm{Cs}$ and $\mathrm{Sr}$ liquids and converted them to suitable solid forms (cesium chloride and strontium fluoride). The solids were encapsulated in stainless steel, and then safely stored in pools. Some capsules were originally released to the public sector for use in sterilization and irradiation facilities, but were later recalled because one of the capsules began leaking. The last capsule was manufactured in 1985. In 1991, DOE determined that updating the deteriorating $B$ Plant to meet current environmental standards was not necessary, and $B \mathrm{Pl}$ ant was precluded from future processing missions. Therefore, the need for WESF to manufacture more capsules was also eliminated. However, the storage of the capsules was still needed. Since that time, WESF has continued to operate, ensuring safe storage and management of the $\mathrm{CS}$ and $\mathrm{Sr}$ capsules and of the substantial radioactive contamination generated during past processing operations.

The WESF Mission Statement and Mission Context Diagram are consistent with the top level ( 0 Cleanup Hanford) and the first and second level functions (4 Remedy Unsafe and Unacceptable Conditions and 4.7 Store, Treat and Disposition Nuclear Materials) identified in WHC-EP-0722 "Systems Engineering Functions and Requirements for the Hanford Cleanup Mission: First Issue."

\subsection{PROBLEM STATEMENT}

WESF continues to perform surveillance, maintenance, and storage since the completion of its previous operational mission of producing encapsulated $\mathrm{Cs}$ and $\mathrm{Sr}$. The past activities left behind an inventory of radioactive and hazardous materials, highly contaminated equipment, and potential contamination of the soil. CS and Sr capsules produced at WESF are located in the facility, at other government laboratories, and at two private companies where the capsules were utilized for sterilization and irradiation purposes. One of the capsules developed a leak; therefore, all of the capsules are being 
returned to WESF for disposition. The continuing operations of ensuring the safe storage and maintenance of the facility and materials are expensive. The aging facility is deteriorating, and the existing confinement systems require safety enhancements. The present implementation of the configuration control system is inadequate, and the current documentation and drawings do not reflect the as-built condition. Currently, WESF relies on $B$ Plant for some of its support systems and waste services which will be unavailable as B Plant is deactivated. Beyond the storage of the $C s$ and $S r$ capsules, no future mission for the WESF has been identified. 


\section{WHC-SD-WM-MAR-007 Revision 0}

\subsection{MISSION ANALYSIS}

\subsection{MISSION STATEMENT}

The WESF Mission is to maintain and upgrade the facility in order to safely store $\mathrm{CS}$ and $\mathrm{Sr}$ capsules while requiring minimal maintenance and surveillance. The WESF and its equipment may need to be improved and modernized to provide this safe storage. Storage will be provided until all of the CS and $\mathrm{Sr}$ capsules have been received and dispositioned for disposal or beneficial uses. Buildings and equipment not required for these activities will be deactivated in preparation for D\&D activities. Currentiy available technologies will be resourcefully applied to maintain and upgrade WESF. This mission will support the Hanford Cleanup Mission Statement from WHC-EP-0722, "System Engineering Functions and Requirements for the Hanford Cleanup Mission: First Issue."

\subsection{INITIAL CONDITIONS}

The initial state conditions for WESF are shown in Table 1. These initial conditions establish the current programmatic and physical states of the system with which the mission is to be performed. Initial state conditions enter from the left as illustrated in Figure 1. References are provided in the table where further information may be found.

\subsection{FINAL CONDITIONS}

Final state conditions for WESF are shown in Table 2. These final conditions establish the programmatic and physical end state to be achieved by execution of the mission. The final conditions are described in terms of major topics. These major topics identify significant system characteristics produced by performing the mission. Final state conditions are shown exiting the right side of the mission as illustrated in Figure 1. 


\section{Control \& Constraints}

Confirmed Policy for Cs and Sr Disposition (TBD)

Stakeholder Acceptance

DOE Orders

ESH Compliance Criteria

Waste Acceplance Criteria

Air Discharge Permit Critera

\section{Initial Conditions}

Cs and Sr Capsules

Cs and Sr Material

Existing Equipment

Ilazardous Chemical \&

Radiological Inventory

Existing Utilities and Services

Aging Confinement Systems

$\sim$ Inadequate Documentation

$\stackrel{\sim}{\sim}$ of Physical Configuration

Contaminated Soil

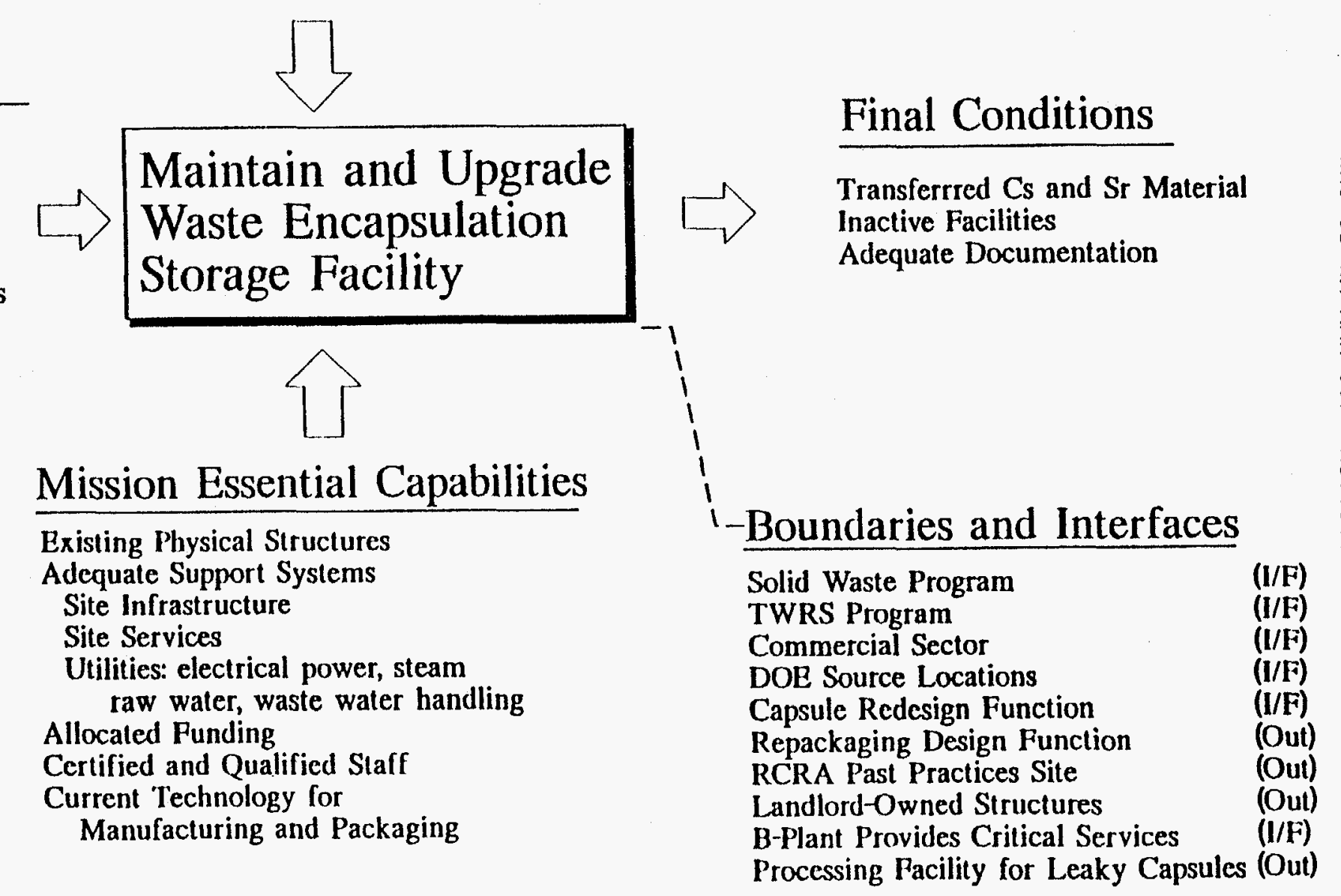




\begin{tabular}{|c|c|c|}
\hline Topics & Initial Condition & References \\
\hline \multicolumn{3}{|l|}{ Physical Systems } \\
\hline Buildings & $\begin{array}{l}\text { Contaminated buildings, most active } \\
\text { One major building. } \\
\text { Degrading confinement systems (glove boxes \& } \\
\text { glass windows). }\end{array}$ & {$[6],.[10]$.} \\
\hline Equipment & $\begin{array}{l}\text { General condition is highly contaminated, both } \\
\text { active and inactive, and outdated and } \\
\text { deteriorating. } \\
\text { Ventilation system. } \\
\text { Eleven pool Cells include pumps, ion exchange } \\
\text { column, leak detectors, monitors, heat } \\
\text { exchangers, instrumentation \& alarms. } \\
\text { Seven Hot Cells include }-20 \text { manipulators and } \\
\text { instrumentation and alarms. } \\
\text { Process Equipment (Oven; feed, storage \& } \\
\text { decontamination tanks, fixtures, etc) } \\
\text { Piping (fixed and embedded) }\end{array}$ & {$[6],.[10]$.} \\
\hline Materials & $\begin{array}{l}\text { Cs and } \mathrm{Sr} \text { capsules both stored at WESF and } \\
\text { inbound from other locations. } \\
\text { Inbound CS and Sr materials. } \\
\text { Radiological contamination \& Hazardous } \\
\text { Chemicals inventory. }\end{array}$ & {$[11],.[13]$.} \\
\hline Utilities \& Services & $\begin{array}{l}\text { WESF infrastructure, wtilities, operating } \\
\text { structure, maintenance are partly shared with } \\
\text { B Plant. } \\
\text { B Plant supplies deionized water, tow level } \\
\text { waste water handling services, sol id waste } \\
\text { handling services and effluent monitoring for } \\
\text { WESF. }\end{array}$ & {$[6],.[10]$.} \\
\hline Soil & Contaminated. & {$[12]$.} \\
\hline \multicolumn{3}{|l|}{ Programmatic Systems } \\
\hline Operational \& Support Personnel & $\begin{array}{l}\text { Trained operations staff. } \\
\text { Shared technical staff. }\end{array}$ & $\begin{array}{l}\text { Training } \\
\text { records. } \\
\text { Organization } \\
\text { chart. }\end{array}$ \\
\hline $\begin{array}{l}\text { Information/ } \\
\text { Documentation }\end{array}$ & $\begin{array}{l}\text { Outdated Safety Analysis report. } \\
\text { Non current as-built documentation of physical } \\
\text { configuration. } \\
\text { Inadequate implementation of configuration } \\
\text { control system. }\end{array}$ & $N / A$ \\
\hline
\end{tabular}




\begin{tabular}{|c|c||}
\hline \multicolumn{2}{|c|}{ Table 2. WESF Final Conditions. } \\
\hline \hline \multicolumn{1}{|c|}{ Topic } & \multicolumn{1}{|c|}{ Final Condition } \\
\hline Transferred Materials & $\begin{array}{l}\text { Capsules and materials are returned to WESF, } \\
\text { and then Cs \& Sr materials have been } \\
\text { transferred for disposition or for beneficial } \\
\text { use. }\end{array}$ \\
\hline Inactive Facilities & $\begin{array}{l}\text { Inactive facilities are available for } \\
\text { beneficial use or are ready for turn over to } \\
\text { deactivation function. }\end{array}$ \\
\hline $\begin{array}{l}\text { Adequate Documentation } \\
\text { and Information Systems }\end{array}$ & $\begin{array}{l}\text { Essential drawings are updated or generated to } \\
\text { reflect the as-built, current configuration, } \\
\text { and the configuration is controlled on selected } \\
\text { systems and equipment. }\end{array}$ \\
\hline
\end{tabular}




\subsection{MISSION BOUNDARIES AND EXTERNAL INTERFACES}

\subsubsection{Mission Boundaries}

The WESF is located in the 200-E area of the U.S. Department of Energy's (DOE) Hanford Site, and is physically attached to the west wall of B Plant. The physical boundary of WESF is described in Table 3 as a list of the structures that are considered part of WESF. The following items are not part of WESF: RCRA past practice sites (cribs, retention basins, B-Ponds) including 216-B-60 Crib located under WESF, TWRS feed lines, 224-B (ventilation and piping interfaces), 222-B, and Mobile Offices (temporary office buildings).

\subsubsection{External Interfaces}

Interfaces occur where information and resources are exchanged in the process of accomplishing the WESF mission. The WESF interfaces with the following programs and projects:

- Private, commercial sector (sending Cs capsules)

- Other DOE locations (sending Cs \& Sr capsules and material)

- Other Hanford Programs and Projects such as

- TWRS Program (receives 1iquid waste stream)

- Solid Waste Program

- Landiord

- Site services (include water sampling \& analytical labs)

- Site infrastructure

- IPM, Initial Pre-treatment Module

- TRUEX, Tranuranic Extraction

- Security, Fire \& Emergency Services

- Engineering Design

- Construction Services 


\begin{tabular}{||l|l|}
\hline \multicolumn{2}{|l|}{ Table 3. WESF Structures } \\
\hline \multicolumn{2}{|c|}{ Number } \\
\hline $225 B$ & Encapsulation Facility \\
\hline $225 B C$ & Compressor Building \\
\hline $225 B D$ & Sampler Building \\
\hline $225 B E$ & Maintenance Building \\
\hline $272 B E$ & Maintenance Building \\
\hline $296 B 10$ & Stack \\
\hline K-1 & Filter \\
\hline K-3 & Filter \\
\hline TK-100 & Waste Water Holding Tank \\
\hline-- & Cooling Tower \\
\hline-- & Emergency Generator \\
\hline C8526 & Electrical Substation \\
\hline N/A & Crane Pad \\
\hline
\end{tabular}




\subsection{MISSION RESOURCES}

Mission resources, also called mission essential capabilities, can be divided into the following categories:

- Allocated funding

- Certified and qualified, intellectual and physical resources

- Current packaging and manufacturing technology

- Physical structures and equipment

- Electrical power, steam, raw water

- Site services \& infrastructure

\subsection{MEASURES OF EFFECTIVENESS AND MEASURES OF SUCCESS}

Measures of effectiveness (MOE) and measures of success are used to determine the progress towards accomplishing the WESF mission. They may also be used to measure the quality of the output and how well the defined objectives were met once the mission is completed. The following is a list of categories of MOE's applicable to WESF (also see Table 4).

\section{Transferred Materials}

- Percentage of capsules which have been returned to WESF

- Amount of material transferred out of the facility for disposition

- Public acceptance

- Risk (to public, environment and workers) is within given constraints (orders, regulations)

\section{Inactive Facilities}

- WESF is ready to be turned over to deactivation function or transferred for beneficial use.

- Required support systems are functional and minimal. HVAC (including the pneumatic supply for operation of ventilation system), electrical power, steam (for heat), raw water (for fire protection), liquid waste services and maintenance services are available for remaining operations. 


\begin{tabular}{|c|c|c|c|}
\hline Final Conditions & $\begin{array}{l}\text { Measure of } \\
\text { Effectiveness }\end{array}$ & $\begin{array}{l}\text { Measure of } \\
\text { Success }\end{array}$ & $\begin{array}{l}\text { Pass/Fail } \\
\text { Threshold }\end{array}$ \\
\hline $\begin{array}{l}\text { Transferred } \\
\text { Materials }\end{array}$ & $\begin{array}{l}\text { Cs and Sr } \\
\text { disposition } \\
\text { procedures }\end{array}$ & Inventory count & $\begin{array}{l}\text { Zero inventory } \\
\text { (Al1 CS and Sr } \\
\text { have been } \\
\text { transferred } \\
\text { elsewhere) }\end{array}$ \\
\hline Facilities & $\begin{array}{l}\text { Limited } \\
\text { operations } \\
\text { (ventilation } \\
\text { needed) } \\
\text { Independent } \\
\text { sources of } \\
\text { electrical power, } \\
\text { steam and raw } \\
\text { water }\end{array}$ & $\begin{array}{l}\text { Buildings } \\
\text { acceptable to } \\
\text { begin transition } \\
\text { and deactivation } \\
\text { Demonstration }\end{array}$ & $\begin{array}{l}\text { Minimal } \\
\text { maintenance and } \\
\text { surveillance } \\
\text { Continued } \\
\text { operations } \\
\text { without B Plant } \\
\text { feeds. }\end{array}$ \\
\hline $\begin{array}{l}\text { Adequate } \\
\text { Documentation and } \\
\text { Information } \\
\text { Systems }\end{array}$ & $\begin{array}{l}\text { Essential } \\
\text { drawings reflect } \\
\text { present. } \\
\text { configuration, } \\
\text { and SAR is } \\
\text { updated. }\end{array}$ & Auditable & $\begin{array}{l}\text { Little or no } \\
\text { discrepancies } \\
\text { found. }\end{array}$ \\
\hline
\end{tabular}


Adequate Documentation and Information Systems

- Percentage of essential drawings updated to as-built, current configuration

- Auditable configuration control system is in place

- Up-to-date Safety Analysis Report (SAR)

Other

- Schedule meets published milestones

- Improvement in public involvement and public perceptions

- Certified and qualified operating and technical staff

- Performance envelopes are prescribed in operating procedures

- Cost is within projected budget.

- Surveillance period is defined.

- Building occupancy level is no higher than needed for minimum surveillance.

- Surveillance and maintenance operating costs.

\subsection{Measures of Mission Risk}

The general mission risks are been identified below. More specific mission risks are described by the key decisions presented in Section 2.8 Issues.

- Public Confidence regarding Environmental, Safety and Health (ESH) Public concern will remain high until distrust of DOE Hanford Operations is mitigated. Characterization and mitigation of all ESH issues and frequent public reporting may eventually result in more public trust of DOE Hanford.

- Technology

The technologies required to execute the WESF mission appear to be available. Currently however, the required ability and resources to provide timely application and integratation of technology to newly emerging contingencies needs constant assessment as the WESF technical baseline evolves.

- Programmatic

Future funding limitations could restrict or jeopardize WESF activities or the duration of the WESF activities. 


\subsection{MISSION FEASIBILITY}

As the WESF functions and requirements analysis is performed and the mission is further defined, mission feasibility will be explored in more depth. Following the requirements identification and their allocation to system functions; detailed alternative solutions will be fully developed, evaluated for feasibility, and the preferred alternative selected.

\subsection{ISSUES}

Workshop discussions with the WESF personnel led to a list of issues which will require resolution to complete the mission successfully. With further group discussion, the 1 ist of issues developed into three categories: key decisions (require that a specific course of action be determined), assumptions, and open issues.

\subsubsection{Key Decisions and Need Dates}

Three key decisions are required and listed below. Each decision contains a title, decision need date, description and justification.

\section{1 - Disposition of CS 137 and $\operatorname{Sr} 90$}

Decision Need Date: No Later Than 30 June 1997

\section{Description:}

System evaluations and possibly major upgrades will be required at the end of WESF's design life, 2004. Without an ultimate disposition date for the $\mathrm{Sr}$ and $\mathrm{Cs}$, determining need and scope of system upgrades becomes complicated. This often leads to "band aid" fixes or incremental upgrades which often cost more than one time expenditures.

\section{Justification:}

The Transuranic Extraction (TRUEX) and Spent Nuclear Fuels projects, as well as commercial vendors, have continued to inquire about other potential uses of WESF $C S$ and $S r$. 
The initial DOE management policy to recall all Cs 137 and Sr 90 capsules when a single unit leaked may have been an overly conservative response, in light of other potential benefits to the public. A public review of the original issues seems warranted either to confirm earlier management perceptions of the degree of public outrage on this issue, or to establish public support for an effort to re-design $C s$ and $S r$ capsules for an eventual return of the material to other beneficial uses.

In addition, the TWRS environmental impact statement (EIS) indicates that WESF-stored $C_{S}$ and $\mathrm{Sr}$ will be transferred to TWRS. The TWRS EIS is useful because it identifies one candidate destination for the Cs and $\mathrm{Sr}$. However, an EIS is not a requirements document. Furthermore, recent decisions regarding the postponement or elimination of vitrification and grouting facilities also brings into question the transfer of $\mathrm{Cs}$ and $\mathrm{Sr}$ to TWRS.

The WESF facility was constructed in 1974. The original design lifetime of the WESF facility is presumed to be thirty years. Ten years from now projects must begin to upgrade building infrastructure subsystems (e.g., wiring, piping, controls) before degradation jeopardizes the safety envelope. Given the seven-year typical lead time required to execute a complete National Environmental Policy Act (NEPA) process, the decisions to plan for these upgrades must be made by WESF management no later than three years from now. This logic represents the basis for the decision need date.

\section{2 - Identification of $\mathrm{CS}$ and $\mathrm{Sr}$ Re-processing Facility (Conditional)}

Decision Need Date: No Later Than 30 June 1997

\section{Description:}

This decision need is contingent upon Key Decision \#1 indicating that CS and $\mathrm{Sr}$ should be returned to other beneficial use. It would also apply in response to capsule integrity failures which are determined to result from design or manufacturing defects. WESF must know whether to augment its mission to accommodate repackaging the $C s$ and $S r$ capsules and/or changing the chemical and/or physical form of the materials.

\section{Justification:}

Two conditions could bring about a need to re-encapsulate the WESF materials, as described below. 
(1) Assuming Key Decision \#1 were to indicate a return to beneficial use in the public sector, an analysis and testing program would have to be completed to determine the adequacy of the present capsules for public usage. If this analysis and testing program were to indicate that the capsules were inadequate, additional functions not presently within the WESF mission would become necessary. These additional functions would include: (a) the design, testing and manufacturing of a new containment design; (b) the transfer of cs and $\mathrm{Sr}$ materials to the new containments; and (c) the disposition of the Cs and $\mathrm{Sr}$ to user sites within the public sector.

(2) The current WESF mission technical baseline includes the capability to identify, isolate, and repair an individual capsule found to be leaking. If an analysis of a leaking capsule were to indicate a design flaw or manufacturing technique problem, an imminent need to repackage more than a few capsules could occur. This situation would warrant an entirely different kind of re-processing capability which would have to be planned and procured.

The indicated decision need date accommodates completing a full NEPA process and beginning required modifications coincident with the first set of WESF design life system upgrades (so there could be one EIS rather than two).

\section{3 - WESF Hot Cells for Other Beneficial Use}

Decision Need Date: No Later Than 30 June 1997

\section{Description:}

By the decision need date WESF management must receive confirmation from other projects of any intended use of WESF hot cells, or WESF will no longer fund maintenance of inactive cells. The cells will still be available, but refurbishment will likely require more effort and funding than if regular maintenance had continued.

\section{Justification:}

WESF hot cells have been the subject of inquiries from other projects and program elements. Other candidate uses have been identified, including TWRS pilot projects and treatability studies related to the IPM (Initial Pretreatment Module). WESF will continue to maintain all its hot cells in a condition suitable for other uses until the decision need date. Beyond the decision need date, WESF will fund only those hot cells necessary to execute the WESF mission to completion. 


\subsubsection{Unvalidated Requirements and Assumptions}

a) For the purposes of this Mission Analysis, the amount of current and future funding was assumed to be adequate to carry out the WESF Mission. As the mission is further defined in the Functional and Requirements Analysis, the funding levels will be established.

b) B-Plant will be deactivated and WESF mission-essential utilities and services will no longer be available. WESF will identify its needed resources. B-Plant will plan, program, and provide WESF stand alone capabilities as part of the B-Plant deactivation baseline.

c) Three pool cell projects which are needed to treat a leaking capsule situation are extensions of the existing WESF capabilities. They will be planned, programmed, and provided within the WESF operational baseline rather than el sewhere.

d) The capability to transfer and receive the incoming $\mathrm{Cs}$ and $\mathrm{Sr}$ is assumed to be available by using existing shipping casks. Other alternatives such as liquid pipelines and vacuum systems are not contained within the WESF Mission.

\subsubsection{Open Issues}

a) The packaging medium for received, unencapsulated materials or for CS/Sr removed from leaking capsules has not been selected. Before any choice can be made all appropriate steps of the Hanford Sitewide systems engineering process will be applied.

b) WESF needs analytical laboratories capabilities available elsewhere on Site to sustain its mission. The analytical laboratories must be capable of receiving and handling radioactive samples. Measurements are needed once per week and include chlorides.(ppm) and total Beta and total Gamma (rad). 


\subsection{REFERENCES}

This document results from the efforts of many people including those working in the B Plant/WESF Transition Project. In addition to meetings held to determine the reports contents and form, other sources were utilized and are listed below:

[1.] WHC-EP-0722, Rev. 0; January 1994; "System Engineering Functions and Requirements for the Hanford Cleanup Mission: First Issue"; Westinghouse Hanford Company.

[2.] WHC-SD-WM-PHA-008, Rev. 0; August 1993; "B Plant Preliminary Hazards Analysis"; Westinghouse Hanford Company.

[3.] 9453650 ATTACHMENT Draft, May 25, 1994, "Hanford Site Systems Engineering Manual" Westinghouse Hanford Company.

[4.] WHC-SD-WM-ZBB-001, Rev 0; March 1, 1994; "B P1ant Complex Zero Based Budget"; Westinghouse Hanford Company.

[5.] EM-40, Draft; Decontamination and Decommissioning Guidance Document; USDOE.

[6.] SD-WM-SAR-005, Rev. 11A; Sept. 22,1993; "Waste Encapsulation and Storage Facility Safety and Analysis Report"; Rockwell International, Hanford Operations.

[7.] WHC-SD-WM-PRS-011, Rev. 0; Oct. 20, 1993; "B Plant Cleanout and Stabilization Program Update FY 1993."

[8.] WHC-SD-WM-AP-023, Rev. 0; Oct. 6, 1992; "B Plant Cleanout and Stabilization Plan."

[9.] 9454364 ATTACHMENT, Rev. 0; May, 1994; "Hanford Site Systems Engineering Management Plan.", Westinghouse Hanford Company.

[10.] ARH-MA-103, Apri] 8, 1973; "Technical Manual for Waste Encapsulation and Storage Facility", Atlantic Richfield Hanford Company.

[11.] DOE/EA-0942, May 1994, "Environmental Assessment, Return of Isotope Capsules to the Waste Encapsulation and Storage Facility", USDOE. 
[12.] WHC-CM-7-8, Vo] 3, (In process of revision), July 1992; "Waste Information Database System, Environmental Engineering and Geotechnology Function Procedures", Westinghouse Hanford Company.

[13.] "Hazardous Material Inventory Database, WESF, dated August 1, 1994 generated by J.C. Dupaquier. 


\subsection{GLOSSARY}

This section contains the definition of words and phrases found in the text of this document.

\begin{tabular}{|l|l|}
\hline active & $\begin{array}{l}\text { This term describes the operational status of a process } \\
\text { or facility. When a facility is active, it is currently } \\
\text { operating or scheduled for operation. }\end{array}$ \\
\hline infrastructure & $\begin{array}{l}\text { Facility infrastructure is the physical portions of the } \\
\text { facility which are implicit to the function of the } \\
\text { activities in the structure, such as the heating } \\
\text { ventilation, electricity etc. } \\
\text { Includes all utility, support and other service systems } \\
\text { that interfere with a particular facility complex. } \\
\text { Within a facility complex ancillary facilities and } \\
\text { structures provide infrastructure support to the main } \\
\text { facility. }\end{array}$ \\
\hline resources & $\begin{array}{l}\text { buildings, equipment, people, materials and chemicals. } \\
\text { shut down }\end{array}$ \\
\hline $\begin{array}{l}\text { Shutdown is a safe, minimal cost surveillance state } \\
\text { awaiting demolition where materials are either safely } \\
\text { stored and maintained in place, removed as waste or } \\
\text { transferred for beneficial use. }\end{array}$ \\
\hline stabilize & $\begin{array}{l}\text { The action of chemically treating the material, } \\
\text { physically repackaging the material or adequately } \\
\text { containing it by sealing or removing the contamination } \\
\text { making it less hazardous. }\end{array}$ \\
\hline
\end{tabular}

